DOI: https://doi.org/10.34069/AI/2021.45.09.30

How to Cite:

Mikhailovich, C.A., Mikhailovna, D.J., \& Anatolievna, M.E. (2021). Lexico-grammatical peculiarities of expressing indefinite semantic subject in russian and english. Amazonia Investiga, 10(45), 302-311. https://doi.org/10.34069/AI/2021.45.09.30

\title{
Lexico-grammatical peculiarities of expressing indefinite semantic subject in russian and english
}

\section{ЛЕКСИКО-ГРАММАТИЧЕСКИЕ ОСОБЕННОСТИ ВЫРАЖЕНИЯ НЕЯВНОГО СЕМАНТИЧЕСКОГО СУБЪЕКТА В РУССКОМ И АНГЛИЙСКОМ ЯЗЫКАХ}

Received: July 18, 2021

Accepted: September 8, 2021

\begin{abstract}
The aim of the study is to investigate the means of representation of the indefinitely expressed subject in Russian and English for the purpose of structuring and classifying the linguistic means of its expression. As the basis for investigation we chose the fictional text of the novel by M. A. Bulgakov "The Master and Margarita" and its parallel translation to English. In the paper we used the method of semantic analysis, contextual component analysis, comparative analysis and the method of linguistic modelling. The scientific novelty of the study consists in the results of the comparative analysis which show that there exist symmetrical and asymmetrical forms of expressing formally indefinite semantic subject. Symmetrical means of implicit expressing semantic subject is mostly nominalization. Generalized subject can be expressed either symmetrically or asymmetrically by various syntactic constructions in Russian and English. Asymmetrical means of expressing semantic subject can be traced in the syntactic constructions of different kind which are represented by binary oppositions. As a result of the research it has been found that the preferred ways of expressing indefinite semantic subject in Russian are indefinite pronouns; in English passive constructions.
\end{abstract}

\author{
Written by: \\ Chervony A. Mikhailovich ${ }^{19}$ \\ https://orcid.org/0000-0002-4587-0195 \\ SPIN-код 1350-1560 \\ Demonova J. Mikhailovna ${ }^{120}$ \\ https://orcid.org/0000-0002-4871-0146 \\ SPIN-код 8820-8200 \\ Murashova E. Anatolievna ${ }^{121}$ \\ https://orcid.org/0000-0002-6018-955X \\ SPIN-код 3786-6495
}

\begin{abstract}
Аннотация
Цель исследования: рассмотреть способы репрезентации неявно выраженного семантического субъекта в русском и английском языках для выявления особенностей его выражения. В качестве материала для исследования нами был использован текст романа М. Булгакова «Мастер и Маргарита» с его параллельным переводом на английский язык. В работе использовались метод семантического анализа, компонентный контекстуальный и сопоставительный методы анализа, а также метод лингвистического моделирования. Научная новизна исследования состоит в сопоставительном анализе языкового материала, который продемонстрировал наличие как симметричных форм выражения формально неявного семантического субъекта, так и асимметричных средств его выражения. К симметричным средствам русского и английского языков имплицитного выражения субъекта относят номинализацию. Обобщенный субъект может быть выражен симметричными и асимметричными синтаксическими конструкциями русского и английского языков. Асимметрия выражения имплицитного субъекта проявляется в
\end{abstract}

\footnotetext{
* (based on the materials of the novel by M. A. Bulgakov "The Master and Margarita" and its translation into English)

${ }^{119}$ Dr. Taganrog Institute named after A.P. Chekov (a branch of) Rostov State University of Economics, Russian.

${ }^{120}$ Ph.D. Taganrog Institute named after A.P. Chekov (a branch of) Rostov State University of Economics, Russian.

${ }^{121}$ Taganrog Institute named after A.P. Chekov (a branch of) Rostov State University of Economics, Russian.
} 


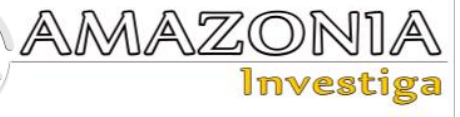

Key words: semantic subject, formal implicitness, symmetry, asymmetry, syntactical construction, comparative analysis.

\section{Introduction}

The relevance of the research is due to the need to consider in a comparative way the means of expression of an implicitly presented semantic subject. This universal phenomenon, which characterizes the dynamism and diversity of linguistic forms, performs an important nominative and communicative function and, as a result, requires its own special consideration.

The doer of the action is always present in human mind and for that reason it always has some kind of omnipresence in speech. So, the active accomplisher or the action is probably the most relevant information, which is encoded into the speech and therefore, it is realized through various linguistic means directly or indirectly.

The purpose and objectives of the study

The purpose of this article is to identify and compare the ways of representing the implicitly expressed semantic subject as it is formulated in Linguistic Encyclopedic Dictionary by Arutyunova (Arutyunova, 1990) in Russian and English. To achieve the set goal of the study, it was necessary to solve the following tasks: 1) to conduct a sample of factual material; 2) classify the types of means of expression of the subject; 3 ) to conduct a comparative analysis of lexical and syntactic forms of expression of an implicit semantic subject; 4) to identify the general and the particular cases in the expression of the implicit semantic subject, which is characteristic of the Russian and English languages.

We used the text of M. Bulgakov's novel "The Master and Margarita"(Bulgakov, 1967) with its parallel translation (Bulgakov, 1967).into English as material for research; разного рода синтаксических конструкциях, представленными бинарными оппозициями. В результате было выявлено: преферентными средствами выражения неявного семантического субъекта в русском языке выступают неопределенно-личные и безличные предложения, в английском пассивные конструкции.

Ключевые слова: семантический субъект, формальная имплицитность, симметрия, асимметрия, синтаксическая конструкция, сопоставительный анализ.

\section{Research problem}

In our research, we develop the problem of the polyphonic expression of the subject in various linguocultures, including Russian and English, paying special attention to the paradigm of the means of expressing an implicitly presented semantic subject, as a universal phenomenon that characterizes the dynamism and diversity of linguistic forms and performs important nominative and communicative functions.

The practical significance of the work lies in the fact that its results can be used in the process of researching the category of "subject", in teaching the comparative typology of English and Russian, the theory and practice of translation, as well as in classes on the semantic grammar of the Russian and English languages.

\section{Theoretical Framework or Literature Review}

The theoretical basis of the research was the scientific works of N.D. Arutyunova, V.G. Gak, V.P. Nedyalkov \& G.G. Silnitsky, V.S. Khrakovsky, E. Benveniste, C.N. Li, S.A. Thompson, J.-M. Merle, M. Noonan, in which the linguistic concept of the subject, its semantic subspecies, as well as the lexicalsemantic and syntactic means of its incomplete formal expression are considered.

\section{Methodology}

The work used the method of semantic analysis, component contextual and comparative methods of analysis, as well as the method of linguistic modeling.

In the contemporary world of total globalization comparative studies of various ontological issues are becoming more and more popular because they are striving for getting the status of linguistic universal laws applicable in any 
language. One of those categories is thought to be the ways of expressing semantic subject.

Search and interpretation of the similarities and differences in lexico-grammatical realizations of the indirect semantic subject in different national linguistic systems, including the Russian and English languages, allows the investigators to approach the principles of deciphering unique codes of the linguistic interpretation of the surrounding reality.

Studies of the classic literary work by M. A. Bulgakov "The Master and Margarita" and its professional translation to English by employing contextual component method allows the researchers to find and systemize symmetric and asymmetric lexical and morph syntactical peculiarities of presenting semantic subject, including ways to express indefinite personal subject, generalized subject and implicit subject. Techniques of the comparative analysis and linguistic modeling method give the opportunity to verify the bases for highlighting certain preferable lexical and morph syntactical means of expressing semantic subject in generalizing expressions in Russian and English bearing in mind the linguistic inner controversies. Those aforementioned include indefinite personal and impersonal sentences in M. A. Bulgakov's original text and passive constructions in the translation. In studying lexical and morph syntactical means of expressing semantic subject the researchers also take into account the statement of the semantic analysis method which is relevant to the modern linguistic anthropocentric and structural systematic paradigms.

Wide variety of methods and techniques allows the researchers to approach the analysis of different ways of representing the indirectly expressed semantic subject in different linguistic systems on the lexical, morphological and syntactic levels. The mentioned above semantic subject is actualized in the identical linguistic context and fulfills same functions from the point of view of realizing various shades of meaning. Lexical and morph syntactical means of expressing semantic subject are also described from the point of view of their distribution which is determined by the conditions of the communicative situation and conventional norms of the Russian and English linguistic systems. Recurrent realization gives rise to viewing those means as a hierarchy which is described in this paper.
These are the aims of the investigation: 1) to conduct a sample of factual material; 2) classify the types of means of expression of the subject; 3 ) to conduct a comparative analysis of lexical and syntactic forms of expression of an implicit semantic subject; 4) to identify the general and the particular cases in the expression of the implicit semantic subject, which is characteristic of the Russian and English languages.

\section{Results and Discussion}

The English language seems to be more formalized and ususal than the Russian language, which has a certain established word order and an abundance of stable grammatical and semantic combinations, each element of which is determined not only by the meaning of the statement, but also by the tradition of use as it was explained by Chomsky in his work Syntactic Structures (Chomsky, 2001). The Russian language, due to its inflectional nature, has a freer word order. These grammatical inconsistencies underlie interlingual asymmetry. Speech represents the most important way of redirecting and externalizing of the human psychological energy and the accomplisher of the action constitutes the most important information for the speaker. On the one hand, it goes without saying, that the focus of attention can be concentrated on the action itself but on the other hand, the doer is always present in the speaker's mind. Since the semantic subject has an infallible realization in speech, the problem lies in the way, how it is actualized and to what extent it is obvious.

The way the semantic subject is grammatically represented in speech tells a lot about the speakers intentions at presenting the information relevant for the purpose of the communication. The most obvious example is the use of passive constructions. The speaker intentionally avoids mentioning the active doer of the action focusing the listener's attention on the accomplishment. The doer in this case can be either obvious or hidden but it does not mean that he or she is taken out of the context completely. What's more, the listener is usually aware of the presence of the doer and understands the purpose of eliminating the subject.

Also, the semantic subject of the utterance can also be expressed by some figurative or idiomatic linguistic means which in its turn enlarges and multiplies the purposes of its nomination manifold. Any figure of speech if used in some figurative sense carries additional information of all sorts; usually it concerns some linguacultural 


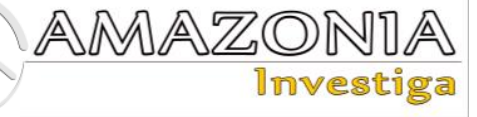

peculiarities of the definite linguaculture. In other words, idiomatic expression of the subject has a many layered semantic structure which consists of direct nominalization of the concrete doer, all kinds of associations aroused by the idiom, some extra linguistic cultural information encoded into the idiom and so on.

The main attention in the article is paid to the unspecified expression of the semantic subject (the term used by Heintz in the book Subjects and Predicables, and later by Merle in the work Le sujet, présentation générale) in the sentences of the Russian and English languages (Heintz, 1973; Merle, 2003). By a semantic subject, we mean an active, intelligent substance, endowed with speech-thinking activity, capable of planning, causating, carrying out and controlling a different degree of complexity of an action - a person.

In the process of work, both symmetrical and asymmetric means of expression (as defined by V.G. Gak in the work Nominalization of the predicate and elimination of the subject. Syntax and stylistics and then enlarged upon in his Asymmetry. Linguistic Encyclopedic Dictionary) were identified (Gak, 1990; Gak, 1998). not fully formally presented or implicitly expressed semantic subject.

As a result of the analysis, syntactic constructions were identified and compared in a comparative way, in which the forms of expression of an implicit subject (largely described previously by Rizzi in the work Comparative Syntax and Language Acquisition) are presented, namely: lexical and grammatical means of expressing an indefinitely personal subject, a generalized subject, an implicit subject (Rizzi, 2000).

\section{Symmetry}

The symmetrical expression of the implicit subject in Russian and English is manifested as a result of the use of subjective and object nominalization in language / speech as it was put by V.G. Gak (Gak, 1976) - expressions of action by a noun.

\section{Subject nominalization.}

For example:

И не тебе, безумный преступник, рассуждать о ней! - тут Пилат вскричал: Вывести конвой с балкона!
And it is not for you, insane criminal, to reason about it!' Here Pilate shouted: 'Convoy, off the balcony!'

The nominalization in this case is quite transparent in both languages; what is more, it is doubled: the personal pronoun is reinforced by the concrete indication to the person meant

Subject nominalization symmetry can also be traced when the active doer is not a person, but some concept; in this case, also in both languages the focus of attention is concentrated on the action and not the recipient:

Признаюсь, этот ответ меня удивил, -мягко заговорил прокуратор, - боюсь, нет ли здесь недоразумения.

'I confess, this answer stuns me,' the procurator began softly, 'I'm afraid there may be some misunderstanding here.

Признаюсь and I confess can also be regarded and complete semantic symmetry of the subject realization with the only difference lying in the grammatical form of expression: explicit versus implicit.

Речь эта, как впоследствии узнали, шла об Иисусе Христе.

This conversation, as was learned afterwards, was about Jesus Christ.

Anthropomorphic action - говорить is carried out without a special lexical marker indicating the communicant (s). According to A. Wierzbicka, the meaning of the action is conveyed by the semantics of lexical units of the Russian and English languages речь conversation (Wierzbicka,1980). This kind of subject nomination is thought to be most obvious and devoid of any implications. From the point of view of the meaning the phrases are identical. Although in the given above example the overlapping of the grammatical forms is not complete; Russian version contains active voice, English - implicit passive. The disagreement can be explained by the difference in the tradition of expression: речь шла can be regarded as a trite metaphor and therefore can't be changed from grammatical perspective. The combination this conversation was about is grammatically free and is understood in the direct sense.

Of course, it is quite obvious that this kind of symmetry in expressing the semantic subject is but most numerous. It contains minimum 
implication and is quite transparent for understanding which, in its turn, is the purpose of everyday communication - to pass on a clear-cut and simple massage which will be understood by the recipient as closely to the original idea as possible.

Object nominalization.

For example: Я лично не вижу ничего дурного в этом звере, чтобы обижаться на это слово... - I personally see nothing bad about this animal, that I should be offended by this word.

Ontologically, слово semantically correlates with such concepts as: речь, говорить. In these examples, the lexical units слово - word denote one of the main functions of the semantic subject and are markers of the speech activity of a formally not designated subject.

Ходатайства того, в лице которого говорит римская власть?

The intercession of him through whose person Roman authority speaks?

In the second example object nominalization works more definitely in the English language where the gender of the doer is actualized, although the message of the excerpt is preserved in both cases, which is to render peculiar stylistic coloring of the utterance.

Кстати, ты знаешь такого, первосвященник? Да... если бы такой проник сюда, он горько пожалел бы себя, в этом ты мне, конечно, поверишь?

Incidentally, High Priest, do you know him? Yes ... if that one got in here, he'd feel bitterly sorry for himself, in this you will, of course, believe me?

Object nominalization despite grammatical identity can differ in semantic value. In the given above example the semantic subject такой/такого has several layers of implication. First of all, it is the generalization of a person referred to, second, the implication of some definite personal characteristics which can be derived only from the context, third, some pejorative connotation about the person described. English him has no such meanings whatsoever; it is definite and direct. That one in the second sentence sounds more general although the demonstrative pronoun narrows the association to one particular person.
Expressing semantic subject through object nominalization is second most widely used way in speech regardless of the language. The reason for that lies in the understanding the general cognitive frame which is typical of human thinking pattern: the subject - the action - the object (reason). This information is imbedded into any message created by human brain and then realized through speech. Grammatical structure of a language proves the aforementioned point, where the semantic core is made up by the subject, the predicate and the object. If for some reason any of the formants is eliminated from the formalized linguistic means, the meaning of it is realized through the rest of the formants implicitly.

So, the semantic subject in the mentioned above case expresses not the active doer but the object at which the action is aimed and which takes the role of the passive accomplisher and takes part in the action indirectly. Here we can talk about different kinds of participants in the action process which, therefore, are differently reflected through grammatical means. The importance of the active and passive doer in the context can be equal; the difference lies in the focus of the speakers attention and the relevance of the message.

Generalized expression of the semantic subject. The generalized expression of the subject is conveyed by words that generalize the gender and number of the real doer as it was proved by A.M. Chervony in his work Semantic subject in generalizing statements of the Russian and French languages. (Chervony, 2019).

For example: А бывает и еще хуже: только что человек соберется съездить в Кисловодск, тут иностранец прищурился на Берлиоза, пустяковое, казалось бы, дело, но и этого совершить не может, так как неизвестно почему вдруг возьмет - поскользнется и попадет под трамвай! Неужели вы скажете, что это он сам собою управил так?

- 'And sometimes it's worse still: the man has just decided to go to Kislovodsk' - here the foreigner squinted at Berlioz - 'a trifling matter, it seems, but even this he cannot accomplish, because suddenly, no one knows why, he slips and falls under a tram-car! Are you going to say it was he who governed himself that way?

In Russian and English, the subject of action is expressed by the generalizing words человек the man, which equally contain the code of both genders, masculine and feminine. Further, in the 


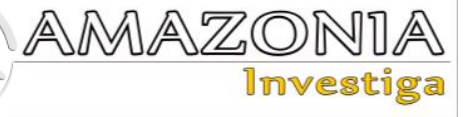

context, the subject is expressed by the postcedent - the pronoun $\mathrm{OH}$, which, according to the Russian grammatical tradition, correlates with the masculine words, in this example - c человеком. In Russian and English, in this kind of cases, there is an asymmetry of the concepts of грамматический род and physiological gender, since the word formally agrees with the masculine pronoun, but both genders are meant. Thus, the subject человек - man in a generalizing sense denotes a representative of both masculine and feminine gender, although this is not entirely characteristic of the English language.

The use in the English language of the substantive man in a generalized meaning instead of the neutral, gender-free noun person is apparently explained by the fact that the speaker is referring to Berlioz, a male representative.

The Russian equivalent of the noun человек man is also used generally in the example below: Да, человек смертен, но это было бы еще полбеды. Плохо то, что он иногда внезапно смертен, вот в чем фокус! И вообще не может сказать, что он будет делать в сегодняшний вечер

'Yes, man is mortal, but that would be only half the trouble. The worst of it is that he's sometimes unexpectedly mortal - there's the trick! And generally he's unable to say what he's going to do this same evening.

The use in the English translation of the articleless noun man, situationally addressed to an individual of the masculine gender, enhances the meaning of generalization and thus does not contribute to the concretization of the real figure. The generalization of the subject plays double role in the speech. On the one hand, the context provides the listener/reader with the exact information about the concrete performer of the activity. On the other hand, the idea is generalized to the level of associations and universal laws so the recipient understands both levels of the embodied meaning simultaneously. Here we can also talk about the third level of associative meaning, which is projected to the recipient of the information. In other words, the listener/reader includes himself or herself into the semantic subject.

Symmetry. Partial expression of the subject's functions. Causative constructions.

In reality, actions are distinguished by their heterogeneity, their diversity and, consequently, the way they are implemented. There are such actions that require a certain beginning, its causation. In this case, the functions of the semantic subject are distributed between the one who causes the action, causates and the one who performs the action. V.P. Nedyalkov and G.G. Silnitsky advocated that in this case, the semantic subject realizes only part of its main functions. Such differentiation is reflected in the language in causative constructions (Nedyalkov, Silnitsky, 1988).

For example:

Не прикажете ли, я велю сейчас дать телеграмму вашему дяде в Киев?.....

Would you like me to have a telegram sent at once to your uncle in Kiev? that is, someone must order me to give a telegram. In the example below, there is a double causation.

The construction of the Russian language has one formally unexpressed causator and a causative subject, designated by the pronoun $\mathbf{9}$, then a description of the activity of this subject follows, the combination велю дать suggests that the action will be carried out by another, implicit agent. In the English version, to express this kind of action, the author also uses a causative construction, the so-called grammatical idiom. In the English translation, the functions of the subject are distributed, the implementation of the action presupposes the participation of you - the equivalent of which is not lexically represented, but morphologically indicated in Russian, me and the alleged agent one, veiled in the causative. Causative constructions in English have a pattern-like form where the initiator of the action and the actual implementer can be a) both grammatically formalized, for example, I'll have him do it and b) the initiator is grammatically expressed and the implementer is not, for example, I'll have it done. In both cases, the object at which the action is aimed is clearly defined and the meaning remains that of the action initiated by one person but accomplished by another.

In Russian there is no specific causative form so the meaning is usually derived from the context and background knowledge. In the phrase $\mathrm{OH}$ строит дом the person indicated by the pronoun $\mathrm{OH}$ will rather be an initiator than the implementer of the action according to common logics although grammatically it is not clearly marked. Still, we can talk about the subject as an active doer and initiator of the activity while the real 
implementer of the activity is only implied as an obvious one.

\section{Asymmetry}

Implicit indefinite subject.

Russian language. Impersonal construction English. Definitely a personal construction.

The Russian language is an adverbial language in which impersonal forms of modality expression are actively used. The equivalent of this kind of construction is quite often English definite personal sentences.

For example: 1) Но об этом можно говорить совершенно свободно. - But we can speak of it quite freely.

The English pronoun we in context expresses a double meaning: on the one hand, the narrator can mean the inner circle of interlocutors, on the other hand, the context is able to expand the number of subjects, thus implying an indefinitely wide range of people.

Надо будет ему возразить так, - решил Берлиоз, - 'I must counter him like this,' Berlioz decided. In the Russian text, the subject is deduced from the communicative situation. Надо будет мне ему возразить.......

In this example, an impersonal construction with a conceivable semantic subject in Russian has an English analogue with a clearly defined subject; although this asymmetry of the formal plan does not affect the semantic plan: the same subject is implied in the Russian language.

O, какой страшный месяц нисан в этом году! $\mathrm{Oh}$, what a terrible month of Nisan we're having this year!

In the given above example the asymmetry in the grammatical subject influences the focus of the semantic meaning priorities. In the Russian version, the idea is that of the difficult month which can be viewed as objective. The English variant contains definite semantic subject we, which changes the meaning from difficult for some objective reasons to difficult for some definite people for the subjective reasons.

There is one more example of this kind of asymmetry which is interesting from the point of view of the meaning shift.
Дело идет к полудню. Мы увлеклись беседою, а между тем надо продолжать

It's nearly noon. We got carried away by our conversation, and yet we must proceed.

Russian construction надо продолжать implies that the is no definite accomplisher of the action, what is more, the person who initiates the action is not the one who fulfills it; it is not quite clear who wants to proceed and who is going to do it. English construction we must lacks any kind of ambiguity; here the initiator and the accomplisher partially coincide because of the plural form of the definite semantic subject. M.S. Vyhrystyuk, and others also thought along those lines in their work Features of the translation of comparisons and emotional and evaluative vocabulary from Russian to English in an artistic text, (Vyhrystyuk, Parshukova, Telitsyna, Onina, 2019).

Russian language. Uncertain Personal Sentence English. Passive construction (largely investigated by V.S. Khrakovsky (Khrakovsky, 1991)).

The first thing to pay attention to is the way of designating an undefined subject of action. In the Russian language, indefinitely personal syntactic constructions are most often used, in which the subject of the action is not formally expressed, but is incorporated into the verb form of the predicate. The simulacrum of the subject in the Russian language is inflection ут(ют), ат (ят).

Such constructions do not exist in the syntactic structure of the English language. In English, such a designation of the subject is conveyed either in a passive form, or using various kinds of formal subjects.

For example:

Над вами потешаться будут. - You'll be laughed at.

A marker in a Russian indefinite-personal sentence with an unnamed indefinite semantic subject is the form of the verb in the future tense. The English version conveys the same meaning with a passive construction. The subject of this phrase is you, which does not correspond to the semantic subject, since it is assumed that it is not вы (you) who will laugh, but at вами (you). The mentioned above feature was widely investigated by many linguists like (Benveniste, 1948; François, 1994; Li, Thompson, 1976; Noonan, 1977). The active subject in the English 


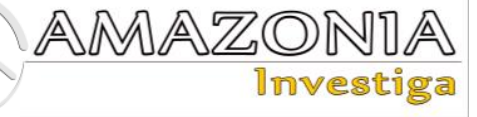

translation is only implied, but in no way encoded in any of the grammatical forms; a passive person is manifested, over whom the action is performed.

Thus, the passive syntactic construction of the English language corresponds to the Russian indefinitely personal sentence.

Consider the following examples:

Это их ввели на помост... - подумал Пилат, а стоны оттого, что задавили нескольких женщин, когда толпа подалась вперед"

They've been led on to the platform,' thought Pilate, 'and the wails mean that several women got crushed as the crowd surged forward.

Вам отрежут голову! Бездомный дико и злобно вытаращил глаза на развязного неизвестного, а Берлиоз спросил, криво усмехнувшись:

\section{- А кто именно? Враги? Интервенты?}

'Your head will be cut off! 'Homeless goggled his eyes wildly and spitefully at the insouciant stranger, and Berlioz asked, grinning crookedly: By whom precisely? Enemies? Interventionists? As in the previous case, the indefinite subject is conveyed in the English language by a passive construction with a supposed agent; further in the context, the subject of action is formalized through interrogative words and the interrogative form of sentences. By expressing the assumption in the text, an attempt is made to identify the real actor (s). In Russian, the participant in the situation is represented by the pronoun вам, in the English sentence it is indicated by the possessive adjective your. In fact, the object of the influence of the implicit subject in the English translation is the somatism head, while in the original there is the object of influence itself and a part of its body - голова.

Let's turn again to the above example, to its inserted part.

Речь эта, как впоследствии узнали, шла об Иисусе Христе.

This conversation, as was learned afterwards, was about Jesus Christ

In Russian, the supposed semantic subject is the pronouns мы or они, which are not formalized in the text, but are easily deduced from the third person plural verb of the past tense узнали. In
English, the formal subject is it, which is omitted in the text, but is easily reconstructed from the logic of the syntactic form, and the pronouns we or they, which, however, are not formalized in any way and are implied based on the semantic meaning of the English syntactic construction, can be a probable semantic subject

Russian language. Uncertainly Personal Construction - English. Definitely a personal construct.

For example: A ты бы меня отпустил, игемон, - неожиданно попросил арестант, и голос его стал тревожен, - я вижу, что меня хотят убить.

'Why don't you let me go, Hegemon?' the prisoner asked unexpectedly, and his voice became anxious. 'I see they want to kill me.'

In this example, a formally unrepresented subject in the indefinitely personal construction of the Russian language is expressed in English by the personal pronoun they. Comparison of the original and its translation showed semantic symmetry (incomplete) and lexical-grammatical asymmetry. In Russian, the subject is hidden or indefinite, although it is morphologically marked with the form of the verb хотят. The formal implementation of the subject by the pronoun they in English also allows the subject to be perceived both indefinitely and quite specifically (they are present, the ones they talked about). This specific feature was mentioned by V.V. Zelenskaya and others in the work ) Innovative Discourse in the Formation of a Modern EthnoCultural Environment. It should be noted: the speaker realizes his pragmatic intention if he knows, but for some reason does not name the real actor (Zelenskaya, Golubtsov, Karabulatova, Kanon, Kasyanova, 2018).

Generalized subject. Russian language. Definitely personal construction - English. An impersonal construction.

В Ершалаиме все шепчут про меня, что я свирепое чудовище... - It is whispered about me in Yershalaim that I am a fierce monster.

In this example, the collective semantic subject Bce is not represented in the English translation.

The subject is implicit in a passive construction with the formal subject it: thus, in the original, the subject is fully expressed, in translation it is not formally represented. It should be noted that in English there are similar ways of expressing a 
subject with a similar meaning: all, everyone, they, so the reasons for such a replacement are not entirely clear. Most likely, during the translation, the main focus was on the process, and not on the subject that produced it.

\section{Semantic asymmetry}

Semantic asymmetry manifests itself primarily at the interlanguage level as a result of inconsistency with the category of number. So, the analogue of the plural subject люди in English is the collective noun people, which is free from any gender differences.

Эти добрые люди, - заговорил арестант и, торопливо прибавив: - игемон, продолжал.......

'These good people,' the prisoner spoke and, hastily adding 'Hegemon', went on......

\section{Conclusions}

A comparative analysis of the linguistic material has demonstrated the presence of both symmetric forms of expression of an implicit semantic subject and asymmetric means of its expression. The symmetrical means of the Russian and English languages include the implicit expression of the subject through subjective and object nominalization.

The generalized subject can be expressed symmetrically - lexical units and asymmetrically - syntactic constructions of the Russian and English languages.

Partial expression of the subject's functions is carried out in Russian and English by sentences with a causative form.

The asymmetry of the expression of the implicit subject is manifested in various syntactic constructions represented by the following binary oppositions: impersonal construction (Russian) - definitely personal construction (English), indefinitely personal sentence (Russian) - passive construction (English), indefinite - personal construction (Russian) definitely personal construction (English).

The preferential means of expressing an implicit semantic subject in Russian are vaguely personal and impersonal sentences, while in English these are passive constructions.

In Russian, due to its inflectional nature and synthetic structure, the semantic subject more often than in English does not find its formal lexical expression in a sentence. An implicitly expressed semantic subject in Russian sentences is marked morphologically: with verbal inflections, it is also revealed by the semantic meaning of the entire utterance (primarily by the semantics of the predicate) and contextually.

The syntactic constructions of the English language, as a formalized language, are characterized by a much more frequent use of lexical units (mainly pronouns) representing the subject.

The research was carried out with the financial support of the Russian Foundation for Basic Research within the framework of the scientific project No. 19-012-00062 "Polyphony of the semantic subject (based on the material of the Russian, French, English and German languages)", conducted at the Rostov State University of Economics (RSUE); Head - Doctor of Philology, Associate Professor, Head of the Department of German and French languages A.M. Chervony

\section{Bibliographic references}

Arutyunova, N.D. (1990). Subject. Linguistic Encyclopedic Dictionary. Moscow: Soviet encyclopedia, $685 \mathrm{p}$.

Benveniste, E. (1948). Noms d'agent et noms d'action en indo-européen. P.: AdrienMaisonneuve, $174 \quad$ p. https://archive.org/details/BenvenisteNomsD agentEtNomsDactionEnIndoEuropeen 1948

Chervony, A.M. (2019). Semantic subject in generalizing statements of the Russian and French languages. Language and reality. Scientific readings at the Department of Romance Languages named after V.G. Gack. Collection of articles on the results of the IV international conference, pp. 432-440. https://www.elibrary.ru/author_items.asp?au thorid $=471853$

Chomsky, N. (2001). Remarks on Nominalization. R.A. Jacobs and P.S. Rosenbaum (eds.). Reading in English Transformational Grammar. Waltham, MA: Ginn, pp. 184-221. https://www.grin.com/document/4808

François, J. (1994). La mise en ordre des relations actancielles : les conditons d'accès des rôles sémantiques aux fonctions de sujet et d'objet. Langages, No. 113, pp. 7-45.

Gak, V.G. (1976). Nominalization of the predicate and elimination of the subject. Syntax and stylistics. Moscow: Nauka, pp. 85-102. 


\section{AMAZONIA
Dnvestiga}

Gak, V.G. (1990). Asymmetry. Moscow: Linguistic Encyclopedic Dictionary, 685 p.

Gak, V.G. (1998). Using the idea of symmetry / asymmetry in linguistics. Linguistic transformations. Moscow: School "Languages of Russian culture", pp. 106-137. https://cyberleninka.ru/article/n/2000-01002-gak-v-g-yazykovye-preobrazovaniya-mshk-yaz-rus-kultury-1998-763-s

Heintz, J. (1973). Subjects and Predicables. The Hague: Mouton and Company, 103 p.

Khrakovsky, V.S. (1991). Passive constructions. The theory of functional grammar. Personality. Pledge. St. Petersburg: Science, St. Petersburg department, pp. 141-180.

Li, Ch. N., \& Thompson, S.A. (1976). Subject and Topic: A New Typology of Language. New York: Academic Press, pp. 457-489.

Merle, J.-M. (2003). The subject, general presentation. The Subject, Language Facts Library, Ophrys, pp. 5-14, Available at: https://hal.archives-ouvertes.fr/hal-00378857 (accessed 02.06.2021)

Nedyalkov, V.P., \& Silnitsky, G.G. (1988). Typology of causative constructions: Morphological causative. Academy of Sciences of the USSR. Institute of Linguistics. Leningrad: Science. Leningrad branch, $311 \quad$ p. $\quad$ URL https://docs.yandex.ru/docs/view?tm=16338 $83760 \&$ tld=ru\&lang=en\&name=nedjalkov_ ed_1988_typology_resultative.pdf\&text=Ne dyalkov\%20V.P.\%2C\%20Silnitsky\%20G.G. \%20(1969).\%20Typology\%20of\%20causati ve\%20constructions $\% 3 \mathrm{~A} \% 20$ Morphological $\% 20$ causative. $\% 20$ Academy\%20of\%20Scie nces $\% 20$ of\%20the\%20USSR.\%20Institute\% 20of\%20Linguistics.\%20Leningrad\%3A\%2 0Science.\%20Leningrad\%20branch $\% 2 \mathrm{C} \% 2$ 0311\%20p.\&url=https\%3A\%2F\%2Filing.sp b.ru $\% 2$ Fdepartements $\% 2$ Ftypology $\% 2$ Fmat erials\%2Fpublications\%2Fnedjalkov_ed_19 88_typology_resultative.pdf $\& 1 \mathrm{lr}=971 \&$ mime
$=$ pdf $\& 110 \mathrm{n}=$ ru\&sign $=94 \mathrm{de} 1346 \mathrm{~b} 6576 \mathrm{e} 9756$ f5d884829bf343\&keyno $=0 \&$ nosw $=1$

Noonan, M. (1977). On Subjects and Topics. Proceedings of the Third Annual Meeting of Berkeley Linguistic Society, Berkeley, California, pp. 372-385. https://journals.linguisticsociety.org/proceed ings/index.php/BLS/article/view/2252

Rizzi, L. (2000). Comparative Syntax and Language Acquisition. London: Routledge, $384 \mathrm{p}$.

Vyhrystyuk, M.S., Parshukova, M.M., Telitsyna, E.L., Onina, S.V. (2019). Features of the translation of comparisons and emotional and evaluative vocabulary from Russian to English in an artistic text. Amazonia Investiga, 8(20), 422-431. Retrieved from https://amazoniainvestiga.info/index.php/am azonia/article/view/172.

Wierzbicka, A. (1980). Lingua mentalis: The Semantics of Natural Language. Sydney: Academic Press, 367 p.

Zelenskaya, V.V., Golubtsov, S.A., Karabulatova, I.S., Kanon, I.A., Kasyanova, Z.S. (2018) Innovative Discourse in the Formation of a Modern Ethno- Cultural Environment. In the: Astra Salvensis, Vol. 6, \#12.

\section{Sources of examples}

Bulgakov M.A. The Master and Margarita (1967): A Novel. LitMir, 416 p. https://www.litmir.me/br/?b=256\&p=1

Bulgakov M. (1967). The Master and Margarita. Translated and with Notes by Richard Pevear and Larissa Volokhonsky. Penguin Books. Available at: https://www.bookfrom.net/mikhailbulgakov/33685the_master_and_margarita.html 